\title{
COPENHAGEN RADIOCARBON DATES VII
}

\author{
HENRIK TAUBER \\ Carbon-14 Dating Laboratory \\ Department of Natural Sciences, National Museum, Copenhagen
}

The following list comprises a selected number of measurements made up to November, 1965. Age calculations are based on a contemporary value equal to $95 \%$ of the activity of the NBS oxalic-acid standard, and on a half life for $\mathrm{C}^{14}$ of $5570 \mathrm{yr}$. Results are reported in years before 1950, and in the A.D./B.C. scale. Errors quoted include the standard deviations of the count rates for the unknown sample, the contemporary value, and the background. Because possible errors arising from isotopic fractionation in the plants, or from the de Vries effect, have not been included, calculated errors smaller than 100 yr have been increased by rounding to that figure as a minimum.

Sample descriptions have been prepared in collaboration with collectors and submitters.

\section{ACKNOWLEDGMENTS}

Part of the work was supported by a grant from the Danish State Research Foundation. Xylotomic determinations on archaeologic samples have been made by E. Tellerup, National Museum of Denmark.

\section{SAMPLE DESGRIPTIONS}

I. GEOLOGIC AND POLLEN-DATED SAMPLES

\section{A. Denmark}

K-931. Eiby, interglacial

Shells (Mytilus edulis) from a cliff formed in till, $\mathrm{N}$ of Eiby Bro $\left(55^{\circ} 42^{\prime} \mathrm{N}\right.$ Lat, $11^{\circ} 50^{\prime} \mathrm{E}$ Long), at Isefjord, Zealand. Found in $50-\mathrm{cm}$ thick layer of stones, $10.5 \mathrm{~m}$ above sealevel, in a 22-m high cliff. At foot of cliff flint material of possible Palaeolithic character was found (Madsen, 1963). Coll. 1964 by E. Madsen; subm. by J. Troels-Smith, Natl. Mus., Copenhagen.

\section{Norre Lyngby profile, Older Dryas period}

Late-glacial samples from open profile in cliff at N $\phi$ rre Lyngby $\left(57^{\circ}\right.$ 25' N Lat, $9^{\circ} 45^{\prime}$ E Long), North Jutland. Profile contains well-known Aller $\phi$ d series described and pollen-analyzed by Iversen (1942). Samples collected in fresh water deposit at level a little below beginning of Aller $\phi \mathrm{d}$ period, belonging to end of Older Dryas, Pollen-zone Ic. Coll. 1949 and subm. by H. Krog, Geol. Survey of Denmark. Comment: Older Dryas period has previously been dated on samples from Usselo, Netherlands (Copenhagen IV), and Witow, Poland (Copenhagen V); dates agree closely. 
K-962. Nørre Lyngby, D.G.U. 251

Strongly compressed, sandy peat with remains of wood and a few bands of moss peat. From upper part (163 to $167.5 \mathrm{~cm}$ below surface) of uppermost of two peat layers placed at base of the fresh water series. Date is average of two measurements: $11,650 \pm 180$ and $11,710 \pm 180$.

K-963. Nørre Lyngby, D.G.U. 252

$11,780 \pm 180$

Strongly compressed, sandy peat with remains of wood. From lower part ( 167.5 to $170 \mathrm{~cm}$ below surface) of same peat layer as K-962.

\section{Sydfynske Øhav, immigration of hazel}

Samples from boring (No. 268) through former fresh water bed in Sydfynske $\varnothing$ hav $\left(54^{\circ} 60^{\prime} \mathrm{N}\right.$ Lat, $10^{\circ} 19^{\prime}$ E Long), S of Funen, Denmark, at water depth of $19.2 \mathrm{~m}$. Pollen-analytically dated to pollen-zone border IV/V, where the hazel curve rises, and to first half of Zone V. Coll. 1963 and subm. by H. Krog. Comment: compare dates for immigration of hazel at the Great Belt, and at Draved (this date list).

K-852. Sydfynske Øhav, D.G.U. 197

$9550 \pm 140$

7600 B.c.

Peat with small amounts of wood and a few fragments of mollusc shells, which were removed by acid before dating. Sample was overlying calcareous gyttja and was covered by peat. Position in core: 165 to 171 $\mathrm{cm}$ below sea bottom. Lower edge of sample marks the pollen-zone border IV $/ \mathrm{V}$.

\section{K-1028. Sydfynske Øhav, D.G.U. 196}

$8990 \pm 140$

Peat with small amounts of wood and fragments of mollusc shells, which were removed by acid before dating. Taken immediately above $\mathrm{K}-852$, covered by peat. Position in core: 158 to $165 \mathrm{~cm}$. Beginning of Pollen-zone V.

K-857. Sydfynske Øhav, D.G.U. 198a

$8910 \pm 140$

6960 B.c.

Wood, presumably exclusively Salix sp., resting on peat and covered by $5 \mathrm{~cm}$ of peat with some gyttja. Position in core: 132 to $148 \mathrm{~cm}$. Pollenzone $\mathrm{V}$, presumably shortly before middle of zone.

\section{Great Belt, immigration of hazel}

Samples from boring (No. 271) through former fresh water bed in Great Belt $\left(55^{\circ} 21^{\prime} \mathrm{N}\right.$ Lat, $10^{\circ} 55^{\prime} \mathrm{E}$ Long), at water depth of $27 \mathrm{~m}$. Pollen analytically dated to Zone IV and beginning of Zone V. Immediately above uppermost sample (K-922) a rise in water level is indicated by the sediments. It is interpreted as the result of a transgression of the sea (Krog, 1960, 1965). This transgression has previously been dated 
(Copenhagen V). Coll. 1964 and subm. by H. Krog. Comment: compare dates for immigration of hazel at Sydfynske $\varnothing$ hav and in Draved (this date list).

K-942. Great Belt, D.G.U. 227

$9730 \pm 130$

7780 B.C. bottom.

Peat from Pollen-zone IV. Position in core: 278 to $281 \mathrm{~cm}$ below sea

\section{K-926. Great Belt, D.G.U. 228}

$9300 \pm 150$

7350 B.c.

Peat from beginning of Pollen-zone V. Frequency of hazel pollen rises from $0.5 \%$ to $10 \%$ of AP. Position in core: 260 to $265 \mathrm{~cm}$ below sea bottom.

K-922. Great Belt, D.G.U. 229

$9060 \pm 120$

Peat from beginning of Pollen-zone V. Hazel curve is still rising strongly. Position in core: 256 to $260 \mathrm{~cm}$, i.e., immediately above K-926, covered by calcareous gyttja. Date is average of two measurements: $8990 \pm 150$ and $9130 \pm 150$.

\section{Draved Mose, Profile H 1312, immigration of hazel}

Samples from profile $(\mathrm{H}$ 1312) in a drainage ditch in the bog Draved Mose $\left(55^{\circ} 1^{\prime} \mathrm{N}\right.$ Lat, $8^{\circ} 57^{\prime}$ E Long), South Jutland; near shore of prehistoric "Draved Lake". A peat monolith, 20 by $20 \mathrm{~cm}$, was cut into contiguous slices, each $1 \mathrm{~cm}$ thick, from which a pollen and a $\mathrm{C}^{14}$ sample was taken (see the following series from Draved Mose). Peat overlies sand; the position in the monolith is indicated in $\mathrm{cm}$ above the sand. Samples date the immigration of hazel, pollen-zone border IV/V. This and the following series from Draved Mose are parts of a project to date pollen-zone borders and characteristic horizons in the total pollen sequence in Draved Mose. Coll. 1963 by Alfred Andersen; subm. by Johs. Iversen, Geol. Survey of Denmark. Comment: the corresponding pollen-zone border IV/V in Süderlügum, only $20 \mathrm{~km} \mathrm{~S}$ of Draved Mose, has been dated as H-363/343, $8720 \pm 140$ B.P. (Kubitzki and Münnich, 1960). Compare also dates for immigration of hazel at Sydfynske $\varnothing$ hav and at Great Belt (this date list).

K-909. Draved Mose, D.G.U. 222

$8730 \pm 160$

Sandy gyttja, 18 to $19 \mathrm{~cm}$ above sand. Pollen-zone border IV/V, the hazel curve rises strongly.

K-910. Draved Mose, D.G.U. 223

$8740 \pm 160$ 6790 B.c.

Sandy gyttja, 17 to $18 \mathrm{~cm}$ above sand, i.e. immediately below K-909. Hazel percentage is very low and probably due to long distance transport. 
K-911. Draved Mose, D.G.U. 224

$8630 \pm 160$

6680 B.c. K-910.

Peaty, sandy gyttja, 16 to $17 \mathrm{~cm}$ above sand, i.e. immediately below

K-913. Draved Mose, D.G.U. 225

$8660 \pm 160$

Peaty, sandy gyttja, 15 to $16 \mathrm{~cm}$ above sand, i.e. immediately below K-911.

\section{Draved Mose, Profile H 1312, Pollen-zones V to VII}

Samples from same profile, $\mathrm{H}$ 1312, in drainage ditch in the bog Draved Mose ( $55^{\circ} 1^{\prime} \mathrm{N}$ Lat, $8^{\circ} 57^{\prime} \mathrm{E}$ Long), South Jutland, as mentioned in the previous series. Samples date from Pollen-zones V, VI, and VII. Coll. 1963 by Alfred Andersen; subm. by Johs. Iversen.

K-950. Draved Mose, D.G.U. 250

$8330 \pm 140$

Peat from 51 to $52 \mathrm{~cm}$ above sand. Taken in layer of birch forest peat which formed after the filling-up of the former lake and before the occurrence of more swampy conditions. Close to a charred layer. Last part of Pollen-zone V.

K-949. Draved Mose, D.G.U. 249

$8190 \pm 140$

6240 B.C.

Peat from 57 to $58 \mathrm{~cm}$ above sand. Taken just below a charred layer and close to level where swamping begins. Pollen-zone border V/VI.

K-948. Draved Mose, D.G.U. 248

$8140 \pm 140$

Peat from 58 to $59 \mathrm{~cm}$ above sand, i.e. immediately above K-949. Taken in a charred layer placed closely above level where swamping begins. Pollen-zone border V/VI.

\section{K-947. Draved Mose, D.G.U. 247}

$7720 \pm 140$

Peat from 68 to $69 \mathrm{~cm}$ above sand. Taken immediately above a charred layer. Pollen-zone border VI/VII ex Knud Jessen; Pollen-zone VI ex Svend J $\phi$ rgensen.

K-946. Draved Mose, D.G.U. 246

$7650 \pm 140$

5700 B.c.

Peat from 77 to $78 \mathrm{~cm}$ above sand. Taken above a charred layer (perhaps from the same fire as in K-947). Pollen-zone border VI/VII ex Knud Jessen; Pollen-zone VI ex Svend J $\phi$ rgensen.

\section{K-945. Draved Mose, D.G.U. 245}

$$
7510 \pm 140
$$

Peat from 82 to $83 \mathrm{~cm}$ above sand. Taken immediately below a distinct charred layer. Pollen-zone VII ex Knud Jessen; Pollen-zone VI ex Svend Jørgensen. 
K-944. Draved Mose, D.G.U. 244

$7180 \pm 120$

5230 в.c.

Peat from 83 to $84 \mathrm{~cm}$ above sand. Taken in charred layer mentioned in K-945. It is possible that part of the peat layer had disappeared in this fire. Pollen-zone VII ex Knud Jessen; Pollen-zone VI ex Svend J $\phi$ rgensen. Date is average of two measurements: $7200 \pm 140$ and $7160 \pm 140$.

\section{Draved Mose, charred pine stumps}

Samples from charred stumps and stems of pine trees from profile $\mathrm{H} \mathrm{1312,} \mathrm{and} \mathrm{from} \mathrm{a} \mathrm{locality} 900 \mathrm{~m} \mathrm{~S}$ of $\mathrm{H} \mathrm{1312,} \mathrm{in} \mathrm{bog} \mathrm{Draved} \mathrm{Mose}$ $\left(55^{\circ} \mathrm{I}^{\prime} \mathrm{N}\right.$ Lat, $8^{\circ} 57^{\prime} \mathrm{E}$ Long), South Jutland. Found at transition from forest peat to sphagnum peat. At this level several charred stumps have been found, and it looks as if forest was destroyed in one big forest fire or in a number of consecutive fires. Samples K-783, K-943, and K-1018 have been dated pollen analytically to the zone border VI/VII ex Knud Jessen. Coll. 1958 to 1965 by Alfred Andersen; subm. by Johs. Iversen.

K-783. Draved Mose, D.G.U. 126

$7810 \pm 140$

Outer year-rings from a charred pine stump found in Profile H 1312.

K-943. Draved Mose, D.G.U. 125

$7840 \pm 140$

5890 в.c.

Charcoal (Pinus sp.) from a charred layer found in Profile H 1312 in connection with $\mathrm{K}-783$.

\section{K-786. Draved Mose, D.G.U. 138}

$7790 \pm 140$

Outer year-rings from a charred pine stump found in southern part of the bog, $900 \mathrm{~m}$ from K-783, in Trench P I at dwelling place No. 332 (see Draved Mose, Mesolithic dwelling places, this date list).

\section{K-1018. Draved Mose, D.G.U. 278}

$7590 \pm 150$

Outer year-rings from a charred pine stump found in Profile H 1312. Stump was partly burned and had been overgrown by the bog when a new pine tree grew up on same spot. Second pine tree had also burned (see K-1019).

K-1019. Draved Mose, D.G.U. 279

$7370 \pm 150$

5420 B.C. K-1018) .

Outer year-rings from younger of two connected pine stumps (see

\section{Draved Mose, Profile 1959, Pollen-zones VII to IX}

Samples from open profile (1959) $30 \mathrm{~m}$ long, in central part of bog Draved Mose (55 $5^{\circ}$ N Lat, $8^{\circ} 57^{\prime}$ E Long), South Jutland. Profile exposes peat from early Atlantic time to present, overlies sand. A peat 
monolith, 20 to $20 \mathrm{~cm}$, was cut into slices $1 \mathrm{~cm}$ thick, from which samples for pollen analysis and for $\mathrm{C}^{14}$ dating were taken. Position of slices in monolith is indicated in $\mathrm{cm}$ above sand. Samples date pollen-zone borders and characteristic horizons in the sequence, among these the land occupation phase (Iversen, 1941). Samples from this monolith representing the pollen-zone border VII/VIII and the elm fall have previously been published (Copenhagen VI). Coll. 1960 by Alfred Andersen; subm. by Johs. Iversen.

K-787. Draved Mose, D.G.U. 177

$6500 \pm 140$

Strongly humified peat (or mor) from 4 to $5 \mathrm{~cm}$ above sand. Pollenzone VII ex Knud Jessen; Pollen-zone VI ex Svend Jørgensen.

\section{K-788. Draved Mose, D.G.U. 178}

$6280 \pm 140$

Strongly humified sphagnum peat from 6 to $7 \mathrm{~cm}$ above sand. Pollen-zone VII ex Knud Jessen; Pollen-zone VI ex Svend J $\phi$ rgensen.

K-830. Draved Mose, D.G.U. 181

$5810 \pm 130$

3860 B.C.

Strongly humified sphagnum peat from 12 to $13 \mathrm{~cm}$ above sand. From level where curve for the mixed-oak forest becomes constant. Pollen-zone VII ex Knud Jessen; Pollen-zone border VI/VII ex Svend J $\phi r-$ gensen.

K-831. Draved Mose, D.G.U. 182

$5710 \pm 130$

Strongly humified sphagnum peat from 14 to $15 \mathrm{~cm}$ above sand. Pollen-zone VII, just above level where curve for the mixed-oak forest becomes constant. Comment: higher samples in same sequence were $\mathrm{K}-737,29$ to $30 \mathrm{~cm}, \mathrm{~K}-738,30$ to $31 \mathrm{~cm}, \mathrm{~K}-739,33$ to $34 \mathrm{~cm}$, and $\mathrm{K}-741$, 35 to $36 \mathrm{~cm}$ above the sand, representing the elm fall and the pollenzone border VII/VIII; see Copenhagen VI.

K-840. Draved Mose, D.G.U. 183

$4480 \pm 120$

Strongly humified sphagnum peat from 41 to $42 \mathrm{~cm}$ above sand. Dates land occupation phase and first occurrence of Plantago lanceolata. Pollen-zone VIII.

K-843. Draved Mose, D.G.U. 184

$4500 \pm 120$

2550 B.c.

Strongly humified sphagnum peat from 43 to $44 \mathrm{~cm}$ above sand. Like K-840, sample dates the land occupation phase and the first occurrence of Plantago lanceolata. Pollen-zone VIII.

K-742. Draved Mose, D.G.U. 160

$2990 \pm 100$

1040 B.c.

Sphagnum peat from 121 to $123 \mathrm{~cm}$ above sand. Taken 1 to $3 \mathrm{~cm}$ below a charred layer found a little below level where beech curve begins. 
Pollen-zone VIII. Date is average of two measurements: $3080 \pm 110$ and $2910 \pm 110$.

K-743. Draved Mose, D.G.U. 161

$2660 \pm 110$

Sphagnum peat from 123 to $124 \mathrm{~cm}$ above sand. Taken immediately below charred layer mentioned in K-742. Pollen-zone VIII.

\section{K-744. Draved Mose, D.G.U. 162}

$2690 \pm 110$

740 B.c.

Sphagnum peat from 125 to $126 \mathrm{~cm}$ above sand. Taken $1 \mathrm{~cm}$ above charred layer mentioned in K-742, and $2 \mathrm{~cm}$ below level where beech curve begins. Pollen-zone VIII.

K.773. Draved Mose, D.G.U. 169

$2730 \pm 110$

Sphagnum peat from 128 to $130 \mathrm{~cm}$ above sand. Dates beginning of beech curve. Pollen-zone border VIII/IX.

K-774. Draved Mose, D.G.U. 170

$2650 \pm 100$

700 B.c.

Sphagnum peat from 131 to $133 \mathrm{~cm}$ above sand. Dates beginning of beech curve. Pollen-zone IX.

K-778. Draved Mose, D.G.U. 171

$1760 \pm 100$

Sphagnum peat from 178 to $180 \mathrm{~cm}$ above sand. Dates a characteristic rise in the curves for beech and hornbeam. Pollen-zone IX.

K-779. Draved Mose, D.G.U. 172

$1730 \pm 100$

Sphagnum peat from 180 to $182 \mathrm{~cm}$ above sand. Dates a characteristic rise in curves for beech and hornbeam. Pollen-zone IX.

K-780. Draved Mose, D.G.U. 173

$1660 \pm 100$

Sphagnum peat from 182 to $184 \mathrm{~cm}$ above sand. Dates a characteristic rise in curves for beech and hornbeam. Pollen-zone IX.

K-745. Draved Mose, D.G.U. 163

$1420 \pm 100$

Sphagnum peat from 206 to $208 \mathrm{~cm}$ above sand. Taken just below lower edge of a characteristic layer of Sphagnum imbricatum peat. Pollen-zone IX.

K-746. Draved Mose, D.G.U. 164

$$
1360 \pm 100
$$

Sphagnum peat from 208 to $210 \mathrm{~cm}$ above sand. Represents lower edge of characteristic layer of Sphagnum imbricatum peat mentioned in K-745. Pollen-zone IX. 
K-747. Draved Mose, D.G.U. 165

$$
1320 \pm 100
$$

Sphagnum peat from 211 to $213 \mathrm{~cm}$ above sand. Taken $3 \mathrm{~cm}$ above lower edge of layer of Sphagnum imbricatum peat mentioned in K-745. Pollen-zone IX.

K-781. Draved Mose, D.G.U. 174

$750 \pm 100$

Sphagnum peat from 244 to $246 \mathrm{~cm}$ above sand. Taken in uppermost part of imbricatum peat layer mentioned in K-745. Pollen-zone IX.

K-782. Draved Mose, D.G.U. 175

A.D. 1170

$780 \pm 100$

Sphagnum peat from 246 to $248 \mathrm{~cm}$ above sand. Taken immediately above imbricatum peat mentioned in K-745. Pollen-zone IX.

\section{Draved Mose, profile at dwelling place No. 329}

Samples from a profile at dwelling place No. 329 (see Draved Mose, Mesolithic dwelling places, this date list) at shore of the prehistoric

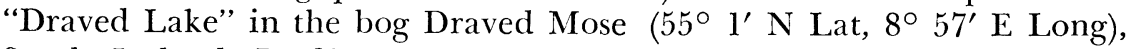
South Jutland. Profile exposes peat layers overlying a sand dune, on which dwelling place No. 329 was found. Samples indicate time when peat formation began on the dune, and date two charred layers in the peat. Coll. 1963 by Alfred Andersen; subm. by Johs. Iversen.

\section{K-918. Draved Mose, D.G.U. 210b}

$2410 \pm 120$

460 B.C.

Strongly humified peat (or mor) from a $1-\mathrm{cm}$ thick layer just above sand. Sample indicates time when peat formation began. Pollen-zone IX.

\section{K-917. Draved Mose, D.G.U. 209}

$$
2190 \pm 120
$$

240 B.C.

Sandy sphagnum peat, 1 to $1.5 \mathrm{~cm}$ thick, from charred layer placed closely above sand. Pollen-zone IX.

\section{K-915. Draved Mose, D.G.U. 208}

$$
2040 \pm 120
$$

90 B.c.

Sandy sphagnum peat, 1 to $1.5 \mathrm{~cm}$ thick, from charred layer placed 25 to $30 \mathrm{~cm}$ above sand. Pollen-zone IX.

\section{K-723. Draved Forest, Mor-profile 1, D.G.U. 135 A.D. 740}

$1210 \pm 100$

Charcoal of oak from a mor-profile in Draved Forest $\left(55^{\circ} 1^{\prime} \mathrm{N}\right.$ Lat, $8^{\circ} 59^{\prime}$ E Long), at L $\phi$ gumkloster, South Jutland. Profile exposed an unusually thick layer of fossil mor overlying eolian sand. The profile is described and pollen-analyzed by Iversen $(1960,1964)$. The charcoal was taken 41 to $45 \mathrm{~cm}$ above sand at border between oak-mor (below) and Callunamor. Pollen-zone IX, shortly before rise of beech curve. Coll. 1959 and subm. by Johs. Iversen. Comment: two lower lying samples from same profile have previously been dated (Copenhagen IV). 
K-794. Lundergaards Mose, D.G.U. 179

$3240 \pm 120$

1290 B.C.

Outer year-rings from oak stump found in Lundergaards Mose $\left(57^{\circ}\right.$ $12^{\circ} \mathrm{N}$ Lat, $9^{\circ} 37^{\prime} \mathrm{E}$ Long) Vendsyssel, North Jutland. Remains of a whole forest have been found in the bog. Trees had been killed, and stumps have been preserved, due to swamping. Sample is from one of the stumps in this forest. Coll. 1962 by J. Jorgensen; subm. by Johs. Iversen.

\section{North Jutland, late-and post-glacial shells}

A series of samples of mollusc shells from late-glacial and postglacial marine deposits in Vendsyssel and Himmerland, North Jutland, and on the island Læs $\phi$, Kattegat. Samples date various stages in the late- and post-glacial marine development in Skagerak and Kattegat (see Hansen, 1965). Three samples of recent shells (K-892, 433, 893) from same area have been included as a control. K-900 coll. ca. 1900 by V. Nordman; K-433 coll. 1952; K-902 and K-903 coll. 1961 by S. A. Andersen; all others coll. 1962-1963 and subm. by H. Krog and Sigurd Hansen, Geol. Survey of Denmark. Comment: before dating, shells were cleaned and the surface layers (approx. 10\% of the total carbonate) were removed with acid.

K-858. Lønstrup Klint, D.G.U. 200

$13,900 \pm 220$

Shells (Saxicava arctica) from layer of Lower Saxicava sand in the cliff L $\phi$ nstrup Klint (5729' N Lat, 9 $9^{\circ} 48^{\prime}$ E Long), Vendsyssel.

\section{K-887. Dybvad Teglvaerk, D.G.U. 211}

$13,180 \pm 200$ 11,230 в.c.

Shells (Saxicava arctica) from clay pit at the brick-works Dybvad Teglværk (57 $16^{\prime} \mathrm{N}$ Lat, $10^{\circ} 21^{\prime} \mathrm{E}$ Long), Vendsyssel. Found in lateglacial Yoldia clay, 1 to $21 / 2 \mathrm{~m}$ below present surface.

\section{K-903. Dybvad Teglvaerk, Andersen No. $2 \quad 13,010 \pm 190$}

Shells (Saxicava arctica) from clay pit at the brick-works Dybvad Teglværk, Vendsyssel. Found in layer of late-glacial Yoldia clay.

K-894. Laes $\phi$ Nordmark, D.G.U. 216

$12,910 \pm 180$

10,960 B.C.

Shells (Saxicava arctica) from boring (No. 7) through late-glacial Yoldia clay at Læs $\phi$ Nordmark (57 $17^{\circ} \mathrm{N}$ Lat, $10^{\circ} 0^{\prime}$ E Long), Læs $\phi$.

\section{K-891. Bindslev Teglvaerk, D.G.U. $213 \quad$ 10,700 в.C.}

Shells (Mya truncata, Saxicava arctica, and Macoma calcarea) from Bindslev Teglværk (57 $32^{\prime} \mathrm{N}$ Lat, $10^{\circ} 12^{\prime} \mathrm{E}$ Long), Vendsyssel. Found in late-glacial Yoldia clay in open profile, covered by late-glacial marine sand. 
K-898. Skeenmфllebaek, D.G.U. 218c

$12,770 \pm 160$

10,820 B.c.

Shells (Mya truncata) from Skeenm $\phi$ llebæk, Loc. A, $\left(57^{\circ} 33^{\prime} \mathrm{N}\right.$ Lat, $10^{\circ} 7^{\prime} \mathrm{E}$ Long), Vendsyssel. Found in transitional layer of marine clay and gravel at border between late-glacial Yoldia clay and lower part of Zirphaea bed. Date is average of two measurements: $12,850 \pm 200$ and $12,690 \pm 200$.

\section{K-897. Skeenm $\phi$ llebaek, D.G.U. 218b}

$12,520 \pm 180$

Shells (Mytilus edulis) from Skeenmollebæk, Loc. A, Vendsyssel. Found in transitional layer of marine clay and gravel at border between late-glacial Yoldia clay and lower part of Zirphaea bed.

K-860. Skeenmøllebaek, D.G.U. 202a

$12,230 \pm 170$

10,280 в.c.

Shells (Mya truncata) from Skeenmollebæk, Loc. A, Vendsyssel. Found in transitional layer of marine clay and gravel at border between late-glacial Yoldia clay and lower part of Zirphaea bed.

\section{K-899. Skeenmфllebaek, D.G.U. 219b}

$12,240 \pm 180$

10,290 B.C.

Shells (Mytilus edulis) from Skeenmфllebæk, Loc. B, Vendsyssel. Found in marine sand belonging to Zirphaea bed, exposed in a cleft cut by a brook, 3 to $4 \mathrm{~m}$ below surface.

K-862. Skeenm $\phi$ llebaek, D.G.U. 203b $12,360 \pm 150$ 10,410 в.c.

Shells (Macoma calcarea) from Skeenmфllebæk, Loc. C, Vendsyssel. Found in marine sand belonging to Zirphaea bed, in a cliff, ca. $3 \mathrm{~m}$ below surface. Date is average of two measurements: $12,460 \pm 170$ and $12,260 \pm 170$.

K-861. Skeenm $\phi$ llebaek, D.G.U. 203a

$12,190 \pm 170$ 10,240 в.C.

Shells (Mya truncata) from Skeenmollebæk, Loc. C, Vendsyssel. From same layer in Zirphaea bed as K-862.

\section{K-859. Borgbakke, D.G.U. 201}

$12,030 \pm 130$ 10,080 B.C.

Shells (Mytilus edulis) from Borgbakke (57 $27^{\prime} \mathrm{N}$ Lat, $10^{\circ} 31^{\prime} \mathbf{E}$ Long), Frederikshavn, Vendsyssel. From layer of shell fragments and marine gravel in Upper Saxicava sand. Date is average of two measurements: $11,840 \pm 170$ and $12,170 \pm 150$.

K-895. Tvaersted Å, D.G.U. 217

$8280 \pm 140$ 6330 B.C.

Shells (Cardium edule) from cliff at the river Tværsted $\AA \quad\left(57^{\circ} 35^{\prime}\right.$ $\mathrm{N}$ Lat, $10^{\circ} 11^{\prime} \mathrm{E}$ Long), Vendsyssel. Found in layer of post-glacial marine sand below Cardium clay, 1 to $21 / 2 \mathrm{~m}$ above water level in river. 
K-906. Melholt, D.G.U. 212d

$6110 \pm 120$

Shells (Ostrea edulis) from gravel pit S of Melholt $\left(57^{\circ} 6^{\prime} \mathrm{N}\right.$ Lat, $10^{\circ} 21^{\prime}$ E Long), Vendsyssel. Found in layer of post-glacial gravel, 0.9 to $1.9 \mathrm{~m}$ above water level of river Gerå. Tapes (Littorina) time. Date is average of two measurements: $6100 \pm 140$ and $6120 \pm 140$.

\section{K-890. Melholt, D.G.U. 212c}

$6090 \pm 120$

Shells (Cardium edule, Ostrea edulis, and Cyprina islandica) from same layer as K-906. Tapes (Littorina) time. Date is average of two measurements: $6050 \pm 140$ and $6130 \pm 140$.

K-907. Melholt, D.G.U. 212e

$5940 \pm 140$ 3990 B.c. time.

Shells (Cardium edule) from same layer as K-906. Tapes (Littorina)

K-888. Melholt, D.G.U. 212a

$5620 \pm 140$

Shells (Ostrea edulis) from same layer as K-906. Tapes (Littorina) time.

K-889. Melholt, D.G.U. 212b

$5560 \pm 140$

3610 B.c. time.

Shells (Cardium edule) from same layer as K-906. Tapes (Littorina)

K-902. Melholt, Andersen No. 1

$5550 \pm 140$

Unsorted shells from same layer as K-906. Tapes (Littorina) time.

K-866. Lille Vildmose, D.G.U. 205

$5580 \pm 150$

Shells (Ostrea edulis) from a digging in Lille Vildmore $\left(56^{\circ} 53^{\prime} \mathrm{N}\right.$ Lat, $10^{\circ} 13^{\prime} \mathrm{E}$ Long), Himmerland. From layer of post-glacial marine sandy gyttja, 2 to $21 / 2 \mathrm{~m}$ below surface. Tapes (Littorina) time.

K.900. Strandby, D.G.U. 220

$4470 \pm 140$

2520 B.C.

Shells (Dosinia exoleta) from beach ridge at Strandby $\left(57^{\circ} 29^{\prime} \mathrm{N}\right.$ Lat, $10^{\circ} 30^{\prime}$ E Long), Vendsyssel.

K-864. Gettrup Bro, D.G.U. 204a

$4150 \pm 140$

2200 в.C.

Shells (Ostrea edulis, Mytilus edulis, Cardium edule, and Tapes aureus) from layer of clayey marine sand with gyttja in river bed of Gerå at Gettrup Bro (57 $7^{\prime} \mathrm{N}$ Lat, $10^{\circ} 17^{\prime} \mathrm{E}$ Long), Vendsyssel, $11 \frac{1}{2} \mathrm{~m}$ below surface. Tapes (Littorina) time. 
K-865. Gettrup Bro, D.G.U. 204b

Shells (Littorina littorea) from same layer as K-864. Tapes (Littorina) time. Date is average of two measurements: $3960 \pm 140$ and $4050 \pm 140$.

\section{K-867. Frederikshavn, D.G.U. 206}

$560 \pm 100$

Shells (Cardium edule) from layer of shells and gravel $\mathrm{N}$ of Frederikshavn (57 $28^{\prime} \mathrm{N}$ Lat, $10^{\circ} 32^{\prime} \mathrm{E}$ Long), Vendsyssel. Found in uncovered surface layer, ca. $2 \mathrm{~m}$ above sealevel. Recent or almost recent.

\section{K-892. Kuje Grund, D.G.U. 214}

$100.8 \pm 0.5 \%$

Shells (Cardium edule) from Kuje Grund $\left(56^{\circ} 57^{\prime} \mathrm{N}\right.$ Lat, $10^{\circ} 17^{\prime} \mathrm{E}$ Long), in Kattegat. Found below surface of Kattegat, $1 / 2$ to $1 \mathrm{~km}$ from shore, covered by ca. $25 \mathrm{~cm}$ of marine sand. Recent.

\section{K-433. Osterskompagniet}

$100.7 \pm 0.5 \%$

Shells (Ostrea edulis) from oyster bed in western part of Limfjorden (57 $\mathrm{N}$ Lat, $9^{\circ} \mathrm{E}$ Long). Living oysters taken 1952.

\section{K-893. Saeby, D.G.U. 215}

$101.9 \pm 0.5 \%$

Shells (Mya arenaria) from beach S of Sæby $\left(57^{\circ} 16^{\prime} \mathrm{N}\right.$ Lat, $10^{\circ} 33^{\prime}$ E Long), Vendsyssel. Recent shells collected on the beach in 1962. Comment: it is not known when the clams were living; the high activity, however, is probably due to an uptake of bomb-produced $\mathrm{C}^{14}$ in the sea.

\section{Faellesvaerre, North Sea transgression}

Samples from salt-marsh sediments found below an artificial mound, Fællesværre ( $54^{\circ} 54^{\prime} \mathrm{N}$ Lat, $8^{\circ} 50^{\prime}$ E Long), South Jutland. The sediments are overlying a sand geest lying 65 to $116 \mathrm{~cm}$ below present sealevel. Samples date latest transgression of the North Sea in the T $\phi$ nder area, South Jutland (Jacobsen, 1964). Coll. 1962 and subm. by N. Kingo Jacobsen, Geog. Inst., Univ. of Copenhagen.

\section{K-795. Faellesvaerre NØ 1}

$3400 \pm 120$

1450 B.c.

Stems and leaves of Phragmites from Phragmites peat formed immediately above the sand geest, 65 to $50 \mathrm{~cm}$ below sealevel.

\section{K-796. Faellesvaerre NØ 2}

$3650 \pm 120$

Piece of wood lying horizontally in red fen peat. Found $45 \mathrm{~cm}$ below sealevel. Immediately below the red fen peat was a charred layer, and below this Phragmites peat overlying the sand geest. 


\section{K-797. Faellesvaerre SV 2}

$1180 \pm 100$

Phragmites washed out of a layer of Phragmites clay formed in brackish water. Found 30 to $40 \mathrm{~cm}$ below sealevel.

\section{K-941. Hollerup, ZMK 31}

$3060 \pm 260$

Bones of amphibians found at Hollerup $\left(56^{\circ} 24^{\prime} \mathrm{N}\right.$ Lat, $9^{\circ} 5 \mathrm{I}^{\prime} \mathrm{E}$ Long), Viborg, Jutland. Supposed to originate from a deposit of kiselguhr formed during the last interglacial, parts of kiselguhr were sticking to the bones. Coll. 1907 by N. Hartz and kept in Zool. Mus. till now; subm. 1964 by U. M $\phi$ hl, Zool. Mus., Copenhagen. Comment: may originate from a burrow of fox or badger dug into the deposit.

\section{B. Greenland}

\section{K-802. Kapisigdlit, "lake 8 m s.m."}

$$
\begin{aligned}
& 4340 \pm 120 \\
& 2390 \text { B.c. }
\end{aligned}
$$

Lake sediments from boring in the first lake ("lake $8 \mathrm{~m}$ s.m.", Iversen, 1954) inland from the mouth, on river Kapisigdlit (64. $26^{\prime} \mathrm{N}$ Lat, $50^{\circ} 12^{\prime}$ W Long), Godhaabsfjord, West Greenland. The sediments consist of gyttja overlying marine clay. Sample taken in lowermost part of gyttja, 0 to $9 \mathrm{~cm}$ above clay. Represents upper part of Pollen Period III (Iversen, 1964). Coll. 1960 and subm. by Bent Fredskild, Natl. Mus., Copenhagen.

\section{Qagssiarssuk, "Comarum Mose"}

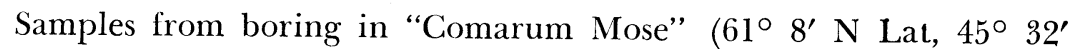
W Long), Julianehåb District, West Greenland. Samples date two pollen horizons in a pollen series from a 445-cm thick organic sediment overlying stratified clay. A pollen diagram from the sediment series is being prepared. Coll. 1960 and subm. by Bent Fredskild.

\section{K-804. "Comarum Mose", Hg 6070}

Noncalcareous, slightly clayey gyttja from the lowermost $10 \mathrm{~cm}$ of the gyttja deposit, overlying stratified clay. Depth below surface 435 to $445 \mathrm{~cm}$. Dates the time when formation of gyttja began.

\section{K-803. "Comarum Mose", Hg 6066}

$2510 \pm 100$

Noncalcareous gyttja with a slight content of swamp peat, taken 0 to $5 \mathrm{~cm}$ below the border between gyttja and overlying swamp peat. Depth below surface 166 to $171 \mathrm{~cm}$. Dates a characteristic horizon in the filling-up of the basin.

\section{Blea Tarn, the elm fall}

\section{England}

Samples from boring (No. 3) in lake sediments in Blea Tarn, $\left(54^{\circ}\right.$ $25^{\prime} \mathrm{N}$ Lat, $3^{\circ} 5^{\prime} \mathrm{W}$ Long), Westmorland, England. Sediments have been 
pollen-analyzed and show a very distinct fall in elm pollen percentages in connection with an inwash of mineral matter (Pennington, 1964 and 1965). Coll. 1964 and subm. by W. Pennington (Mrs. T. G. Tutin), Univ. of Leicester, England. Comment: dates agree closely with other dates for the post-glacial elm fall in NW Europe (Godwin, 1960; Copenhagen VI).

$5530 \pm 120$

K-959. Blea Tarn, No. 6-7

3580 B.C.

Noncalcareous gyttja from layers Nos. 6 and 7,190 to $200 \mathrm{~cm}$ in the core. Before the elm fall, elm pollen frequencies fall from $20 \%$ to $14 \%$ of AP.

K-958. Blea Tarn, No. 4-5

$5320 \pm 120$

3370 B.c.

Noncalcareous gyttja from layers Nos. 4 and 5,180 to $190 \mathrm{~cm}$ in the core, i.e., immediately above K-959. Before the elm fall, elm pollen frequencies rise from $14 \%$ to $16 \%$ of AP.

K-957. Blea Tarn, No. 2-3

$5100 \pm 120$

3150 B.C.

Noncalcareous gyttja from layers Nos. 2 and 3,170 to $180 \mathrm{~cm}$ in the core, i.e., immediately above K-958. Represents the true elm fall, elm pollen frequencies fall from $16 \%$ to $6 \%$ of AP.

\section{ARCHAEOLOGIC SAMPLES}

\section{A. Denmark}

\section{Draved Mose, Mesolithic dwelling places}

Samples from 4 Mesolithic dwelling places found at shores of the prehistoric "Draved Lake" in Draved Mose $\left(55^{\circ} 1^{\prime} \mathrm{N}\right.$ Lat, $8^{\circ} 57^{\prime} \mathrm{E}$ Long), South Jutland. Dwelling places have been found on former sand dunes, now covered by peat. Flint implements found are from Klosterlund and younger cultures (Kapel, 1959, 1964). Coll. 1958-1965 and subm. by Alfred Andersen and H. Kapel, Geol. Survey of Denmark. Comment: a sample from dwelling place No. 604 has previously been dated to K-582, $9060 \pm 130$ (Copenhagen V). Dates support the archaeological assumption that remains from two different cultures are left on these places.

\section{K-829. Draved Mose, D.G.U. 112 and 114}

Charcoal from thin culture layer (4 to $6 \mathrm{~cm}$ in thickness) on dwelling place No. 604, found together with flint implements from Klosterlund culture. The implements may originate from two different cultures (see K-582, Copenhagen V), which have not yet been properly separated. Found in Squares H I and H II. 
K-790. Draved Mose, D.G.U. 141

$8990 \pm 140$

7040 B.c.

Charcoal of pine and birch from culture layer on dwelling place No. 611. Core axes, trimmed blades and microliths from Klosterlund culture were found in the culture layer. Sample found in pit, Trench $\varnothing-V$, Squares 11 to 12.

\section{K-791. Draved Mose, D.G.U. 148}

$8430 \pm 140$

Charcoal of pine and birch from culture layer on dwelling place No. 332. Found together with flint implements, e.g., core axes, scrapers, and microliths, and with larger worked stones. Implements are supposed to be somewhat younger than Klosterlund culture. Sample collected from a number of squares.

\section{K-914. Draved Mose, D.G.U. 188}

$9050 \pm 160$

Chacoal from culture layer on dwelling place No. 329. Flint implements from two different cultures have been found in the culture layer, partly from Klosterlund culture, partly from another probably younger culture with small and finely worked microliths. Sample collected in Square $24 / 3 \mathrm{~W}$.

K-841. Draved Mose, D.G.U. 187

$\mathbf{8 4 7 0} \pm 150$

6520 B.c.

Charcoal from culture layer on dwelling place No. 329. Found in Square $25 / 3 \mathrm{~W}$ in same culture layer as K-914.

K-1017. Draved Mose, D.G.U. 282

$8250 \pm 170$

6300 B.c.

Charcoal of pine from culture layer on dwelling place No. 329. Found on Square $32 / 8 \mathrm{~W}$.

\section{K-1016. Draved Mose, D.G.U. 281}

$8180 \pm 190$

Charcoal of pine from dwelling place No. 329. Found in pit in southern slope of sand dune, on top of which the dwelling place was situated. Pit also contained pieces of worked flint. From Square $32 / 3 \mathrm{~W}$.

\section{Kongemose culture, Åmosen}

Samples of charred wood from culture layer on dwelling place Kongemosen (55 $35^{\prime} \mathrm{N}$ Lat, $11^{\circ} 30^{\prime} \mathrm{E}$ Long), in bog Åmosen, West Zealand. Found in a 5 to $17-\mathrm{cm}$ thick refuse layer embedded in gyttja in a former lake, on the shore of which the dwelling place was situated. A very large amount of flint implements were found on the dwelling place, among these rhombic arrow heads and large flint picks. Kongemose culture is an inland phase of the Mesolithic Old Coastal culture (Jorgensen, 1956 and 1961). A preliminary pollen investigation has dated the refuse layer to the transition Pollen-zone V/VI. Coll. 1955 and subm. by Svend J $\phi r-$ gensen, Natl. Mus., Copenhagen. 
K-571. Kongemosen, No. 3571

Charred wood of pine from refuse layer in calcareous gyttja. Found in lowermost part of refuse layer, which here was $17 \mathrm{~cm}$ thick. Date is average of two measurements: $8980 \pm 150$ and $8720 \pm 130$.

K-570. Kongemosen, No. 20181

$8400 \pm 150$

Charred wood from same refuse layer as in K-571. Found at a place where refuse layer was only 5 to $8 \mathrm{~cm}$ thick.

\section{K-978. Katbjerg, Early Passage Grave period 2540 B.c.}

Bark (Betula sp.) from a passage grave, Jordh $\phi$ j, at Katbjerg $\left(56^{\circ}\right.$ $38^{\prime} \mathrm{N}$ Lat., $9^{\circ} 55^{\prime} \mathrm{E}$ Long), Jutland. Found jammed in between stones in wall of grave, which had remained untouched from the Stone age until the opening in 1890. The passage grave belongs to Middle Neolithic time, Period I b. Coll. 1890 by W. Boye; subm. by P. Kjærum, Prehist. Mus., Aarhus. Comment: two samples from Early Passage Grave period in Jutland have previously been dated (Copenhagen VI). Dates agree closely. The bark had not been treated with preservatives.

\section{K-989. Fårup, dise wheel}

$3460 \pm 100$

1510 B.c.

Wood (Quercus sp.) from disc wheel found in 1875 in bog at Fårup $\left(56^{\circ} 22^{\prime} \mathrm{N}\right.$ Lat, $9^{\circ} 33^{\prime} \mathrm{E}$ Long), Jutland. Wheel is of the one-piece type, which in the Netherlands has been dated to ca. 2100 B.c. (van der Waals, 1964) . Coll. 1875; subm. by H. Norling-Christensen, Natl. Mus., Copenhagen. Comment: sample had been treated with preservatives, presumably varnish and kerosene. Prior to dating preservatives were extracted with ether, and the sample material separated in cellulose and lignin fractions as described in K-599 (Copenhagen V). The two fractions were dated separately: K-989A (lignin), $3410 \pm 110$; and K-989B (cellulose), $3510 \pm 110$. Date is average of these two measurements.

$2420 \pm 110$

K-823. Dystrup Mose, disc wheel

470 в.c.

Wood (Alnus sp.) from disc wheel found in 1904 in Dystrup Mose ( $56^{\circ} 27^{\prime} \mathrm{N}$ Lat, $10^{\circ} 38^{\prime} \mathrm{E}$ Long), Jutland. Wheel is of tripartite type with lunate openings and separate inserted nave (Müller, 1907). In the Netherlands this type of disc wheel has been dated to the Iron age (van der Waals, 1964). Coll. 1904; subm. by Elna M $\phi$ ller, Natl. Mus., Copenhagen. Comment: sample had been treated with paraffin as a preservative. Prior to dating the paraffin was carefully extracted by repeated leaching with ether, which in turn was extracted by several boilings with water. After drying no smell of paraffin or ether was left. Date is average of two measurements on the thus pretreated material: $2410- \pm 120$ and $2430 \pm 120$. As a control a wood sample previously dated to K-101, 
$10,970 \pm 120$ (Copenhagen VI) was given the same treatment with ether and water. After this pretreatment the date became $10,990 \pm 180$.

\section{Viking ships, Roskilde Fjord}

Samples from Viking ships and artificial blockings found in natural channels at Skuldelev ( $55^{\circ} 48^{\prime} \mathrm{N}$ Lat, $12^{\circ} 4^{\prime} \mathrm{E}$ Long), in Roskilde Fjord, Zealand. Five wrecks of old Viking ships were found in a submarine excavation. The ships had been sunk deliberately in order to block the narrow natural channel, Peberrenden, to the town Roskilde, probably for defense (Olsen and Crumlin-Pedersen, 1958; Olsen, 1964). Blockings of piles driven into the bottom were also found in the channel Peberrenden, and in three other narrow channels: Vesterrenden, Vimmelskaftet, and Jydedybet. Coll. 1962 and subm. by Oluf Olsen and O. Crumlin-Pedersen, Natl. Mus., Copenhagen. Comment: two samples from wreck No. 2 have previously been dated with similar results (Copenhagen IV).

\section{K-876. Skuldelev, wreck No. 1}

$940 \pm 100$

Animal hair and wood-tar used as caulking between the planks in wreck No. 1. Dates time of construction of the ship.

\section{K-908. Skuldelev, wreck No. 2}

$960 \pm 100$

Wooden pins (Salix sp.) used in construction of wreck No. 2. Wedges of hard wood (oak) were driven into the pins to make them stick in the holes; wedges were removed before dating. Dates time of construction of the ship.

\section{K-877. Skuldelev, wreck No. 3}

Wooden pin (Salix sp.) used in construction of wreck No. 3. Dates time of construction of the ship.

K-875. Skuldelev, wreck No. 5

Animal hair and wood-tar used as caulking between the planks in wreck No. 5. Dates time of construction of the ship.

\section{K-878. Skuldelev, Peberrenden}

$970 \pm 100$

Branches (Corylus avelana) used in pile blocking in the channel Peberrenden, found immediately E of wreck No. 3.

\section{K-873. Skuldelev, Vesterrenden}

$$
940 \pm 100
$$

Piece of pile (Fagus sylvatica) used in blocking in the channel Vesterrenden. 


\section{K-871. Skuldelev, Vimmelskaftet}

Wood from piles (Fagus sylvatica) used in blocking in the southern end of the channel Vimmelshaftet.

K-872. Skuldelev, Jydedybet

$870 \pm 100$

Piece of worked wood (Quercus sp.), perhaps from a ship, used as blocking in the channel Jydedybet. Date is average of two measurements: $860 \pm 100$ and $880 \pm 100$.

\section{B. Greenland}

\section{Jørgen Brønlund Fjord, Vandfaldnaes}

Samples of charcoal from terraces at Vandfaldnæs $\left(82^{\circ} 9^{\prime} \mathrm{N}\right.$ Lat, $30^{\circ} 13^{\prime} \mathrm{W}$ Long), J $\phi r g e n$ Br $\phi$ nlund Fjord, Peary Land. Two raised beaches at levels of $11 \mathrm{~m}$ and $6.4 \mathrm{~m}$ above sealevel, respectively, are found at the locality. The charcoal originates from Palaeo-Eskimo ruins on these terraces. The ruin on the $11 \mathrm{~m}$ terrace contained implements of Independence I culture, while the ruin on the lower terrace represents Independence II culture (Knuth, 1965). Coll. 1963 and subm. by Eigil Knuth, Natl. Mus., Copenhagen. Comment: ruins from Independence I culture have previously been dated on samples of drift wood (Copenhagen III, IV, and VI). This (K-932) and the following samples from Portfjældet and from Pearylandville are the first clates of Independence I culture made on local plant material (Salix arctica). Dates agree closely with those previously made on driftwood. Dates for Independence II culture agree with those previously published (Copenhagen III and IV).

\section{K-932. Vandfaldnaes, $11 \mathrm{~m}$ terrace}

Charcoal (Salix sp.) from ruin No. 15 on the $11 \mathrm{~m}$ terrace, found together with a large number of implements of Independence I culture.

\section{K-933. Vandfaldnaes, $6.4 \mathrm{~m}$ terrace, No. 1}

Charcoal from drift wood (Larix sp.) from a large circular ruin, No. 9, with mid-passage hearth, situated on the $6.4 \mathrm{~m}$ terrace. Found together with implements of Independence II culture.

K-934. Vandfaldnaes, 6.4 $\mathrm{m}$ terrace, No. 2

Charcoal from drift wood (Picea sp.) from same ruin as K-933. Dated in order to trace a possible difference between different pieces of drift wood from the same ruin. Date is average of two measurements: $2720 \pm 110$ and $2760 \pm 120$.

\section{Midsommerelven, Portfjaeldet}

Charcoal from local willow found in Palaeo-Eskimo ruins on a terrace $9 \mathrm{~m}$ above bed of the river Midsommerelven at Portfjældet $\left(82^{\circ} 12^{\prime}\right.$ 
$\mathrm{N}$ Lat, $32^{\circ} 20^{\prime} \mathrm{W}$ Long), Peary Land. Two of the ruins contained implements of Independence I culture (Kuth, 1965). Coll. 1963 and subm. by Eigil Knuth. Comment: see comment to samples from Jørgen Brønlund Fjord, Vandfaldnæs (this date list).

\section{K-928. Portfjaeldet, ruin No. 1}

$3890 \pm 120$

Charcoal (Salix sp.) found in ruin No. 1. Ruin contained no implements.

\section{K-929. Portfjaeldet, ruin No. 2}

$3860 \pm 120$

Charcoal (Salix sp.) found in ruin No. 2, an eliptic camp site with mid-passage hearth. Found together with implements of Independence I culture.

K-930. Portfjaeldet, ruin No. 3

$3790 \pm 120$

Charcoal (Salix sp.) found in ruin No. 3, which was situated $20 \mathrm{~m}$ $\mathrm{W}$ of ruin No. 2. Found together with implements of Independence I culture.

\section{Nedre Midsommers $\phi$, Pearylandville}

Charcoal from local willow found in ruins on a large ruin place Pearylandville $\left(82^{\circ} 14^{\prime} \mathrm{N}\right.$ Lat, $33^{\circ} 31^{\prime} \mathrm{W}$ Long), at the lake Nedre Midsommers $\phi$, Peary Land. Implements of Independence I culture were found in the ruins (Knuth, 1965). Coll. 1964 and subm. by Eigil Knuth. Comment: see comment to samples from J $\phi$ rgen Bronlund Fjord, Vandfaldnæs (this date list).

\section{K-938. Pearylandville, ruin No. 24}

$3950 \pm 120$

Charcoal (Salix sp.) from ruin No. 24. A large number of implements of Independence I culture was found in the ruin, together with bones of musk-ox, hare, and trout.

\section{K-939. Pearylandville, ruin No. 10}

Charcoal (Salix sp.) from ruin No. 10. Found together with implements of Independence I culture and bones of musk-ox, hare, and trout.

\section{K-1004. Nedre Midsommers $\phi$ Teltnaes A.D. 1180}

$770 \pm 100$

Charcoal (Salix sp.) from hearth in front of a ruin at Teltnæs $\left(82^{\circ}\right.$ $14^{\prime} \mathrm{N}$ Lat, $33^{\circ} 0^{\prime} \mathrm{W}$ Long), at the lake Nedre Midsommers $\phi$, Peary Land. The ruin (No. 2), a tent ring, was situated on a gravel terrace $3.4 \mathrm{~m}$ above water level of the lake. Form of the ruin is different from all other ruins in the area. Supposed to represent an immigration younger than Independence II culture. Coll. 1964 and subm. by Eigil Knuth. 


\section{K-855. Ika, Sarqaq culture}

$$
3360 \pm 120
$$

Charcoal (Picea sp.) from driftwood found in campsite at Ika, Ikamiut $\left(65^{\circ} 38^{\prime} \mathrm{N}\right.$ Lat, $52^{\circ} 48^{\prime} \mathrm{W}$ Long), Sukkertoppen, West Greenland. Collected from 5 hearths within the campsite, situated 10 to $20 \mathrm{~cm}$ below the present surface. Found together with implements of Sarqaq culture. Coll. 1963 and subm. by Robert Petersen, Natl. Mus., Copenhagen. Comment: samples from Sarqaq culture have previously been dated (Copenhagen III, IV, V; Pennsylvania IV).

\section{Iceland}

\section{K-940. Ingolfur Arnarson's farm}

$1340 \pm 100$

A.D. 610

Charcoal powder (probably of birch) mixed with clay, from culture layer found at the supposed site of Ingolfur Arnarson's farm, Reykjavik $\left(64^{\circ} 8^{\prime} \mathrm{N}\right.$ Lat, $21^{\circ} 56^{\prime} \mathrm{W}$ Long), Iceland. Culture layer (perhaps a floor) was found $1.85 \mathrm{~m}$ below present surface, and $1.3 \mathrm{~m}$ below a level, which with great probability dates from the earliest days of the town Reykjavik, A.D. 1750 to 1760 . The farm of Ingolfur Arnarson, one of the founders of the Norse settlement on Iceland, dates from A.D. 874. Coll. 1963 and subm. by K. Eldjarn, Natl. Mus. Reykjavik. Comment: date is somewhat older than expected, but it is not incompatible with assumption that the culture layer dates from the time of Ingolfur Arnarson.

\section{Witow series}

\section{Poland}

Charcoal from culture layers found in profile through sand dunes and a bog at Witow $\left(52^{\circ} 4^{\prime} \mathrm{N}\right.$ Lat, $19^{\circ} 11^{\prime}$ E Long), Province of Lodz, Poland. Profile exposed a number of culture layers separated by sand. Culture layers date from Aller $\phi d$ time and till Neolithic (Chmielewska and Chmielewski, 1960). Coll. 1961 and subm. by M. Chmielewska, Archaeol. Mus., Lodz.

\section{K-952. Witow, 1-P}

$11,020 \pm 170$

9070 B.c.

Charcoal (Pinus sp.) from layer No. 4a, presumably a deflated culture layer, in Horizon $B$ which is separating sand dunes from Older Dryas and Younger Dryas. Probably of Aller $\phi$ d age. Comment: date agrees well with an Aller $\phi$ d age.

K-954. Witow, 6-P

$8180 \pm 140$

6230 B.c.

Charcoal (Pinus sp.) from layer No. 21, a sandy culture layer on slope of a dune in marginal zone between dune and bog. Mesolithic culture layer with flint implements of Tardenoisian type. 
K-953. Witow, 3-P

$3410 \pm 110$

Charcoal (Quercus sp.) from layer No. 13, a sandy culture layer on slope of a dune in marginal zone between dune and bog. Neolithic layer from Pre-Finno-Ongrian time.

\title{
E. Qatar
}

$4100 \pm 110$

\section{K-967. Bir Uwainat Ali}

2150 B.c.

Shells (Cerithium sp.) from layer of shells of Cerithium sp. and Columbella sp. found immediately below dwelling place $Q 62 / 10$ at Bir Uwainat Ali (25 $28^{\prime} \mathrm{N}$ Lat, $50^{\circ} 45^{\prime}$ E Long), Qatar. Sample antedates the dwelling place. Coll. 1964 and subm. by Svend J $\phi$ rgensen and $\mathrm{H}$. Kapel, Natl. Mus., Copenhagen.

\section{K-971. Shaqah}

$6970 \pm 130$

Sand with slight amount of charcoal powder from fireplace in a culture layer found $6 \mathrm{~km} \mathrm{SE}$ of Shaqah $\left(24^{\circ} 45^{\prime} \mathrm{N}\right.$ Lat, $51^{\circ} 25^{\prime} \mathrm{E}$ Long), Qatar. Culture layer was covered by $60 \mathrm{~cm}$ of sand. Artifacts in layer are presumably of same age as the Mesolithic Al Wusail find (Nielsen, 1962) . Coll. 1964 and subm. by Svend Jørgensen and H. Kapel.

Date lists:

\section{REFERENCES}

\author{
Copenhagen III Tauber, 1960 \\ Copenhagen IV Tauber, 1960 \\ Copenhagen V Tauber, 1962 \\ Copenhagen VI Tauber, 1964 \\ Pennsylvania IV Ralph and Ackerman, 1961
}

Chmielewska, M. and Chmielewski, W., 1960, Stratigraphie et chronologie de la dune de Witow, distr. de Leczyca: Biuletyn Peryglacjalny (Poland), no. 8.

Godwin, H., 1960, Radiocarbon dating and Quaternary history in Britain: Royal Soc. (London), Proc., ser. B, v. 153, p. 287-320

Hansen, Sigurd, 1965, The Quaternary of Denmark, p. 1-90: in Rankama, E. (Ed.), The Quaternary: Interscience Publishers, New York, v. 1.

Iversen, Johs., 1941, Land Occupation in Denmark's Stone Age: Danm. Geol. Unders $\phi$ gelse, ser. II, no. 66, p. 1-68. 1942, En pollenanalytisk tidsfæestelse af Ferskvandslagene ved Nørre
Lyngby: Medd. Dansk Geol. Forening, v. 10, p. 130-151. analysis: Oikos, v. 4, p. 85-103.

ering of pollen

1960, Problems of the early Post-glacial forest development in Denmark: Danm. Geol. Undersøgelse, ser. IV, v. 4, no. 3, p. 1-32. Ecology, v. 52 (suppl.), p. 59-70.
(antional succession in the Post-glacial: Jour. Jacobsen, N. Kingo, 1964, Traek af Tøndermarskens naturgeografi (summary in Eng-
lish): C. A. Reitzel, Copenhagen, p. 1-350.

Jørgensen, Sv., 1956, Kongemosen. Endnu en Åmose-boplads fra ældre stenalder (summary in English): Kuml 1956, p. 23-40. 1961, Zur Frage der ältesten Küstenkultur in Dänemark: Internat. Kongr.
für Vor- und Frühgeschichte, V, Hamburg 1958, Ber., p. 440-447.

Kapel, H., 1959, En uforstyrret stenalderboplads ved Draved: Sønderjysk Månedsskrift, v. 35 , no. 8 , p. 161-165. 
1964, Nyere arkæologiske undersøgelser i Tønder og Åbenrå amter: Sønderjyske Årbøger 1964, p. 253-260.

Knuth, E., 1965, Second and Third Peary Land Expedition, 1963 and 1964: The Polar Record, v. 12, no. 81, p. 733-738.

Krog, H., 1960, Post-glacial submergence of the Great Belt dated by pollen analysis and radiocarbon: Internat. Geol. Cong., $21^{\text {st }}$, Copenhagen 1960, Rept., v. 4, p. 127-133. 1965, On the Post-glacial development of the Great Belt: Baltica, v. 2, p. 47-60.

Kubitzki, K. and Münnich, K. O., 1960, Neue $C^{14}$ Datierungen zur nacheiszeitlichen Waldgeschichte Nordwestdeutschlands: Ber. Deutsch. Bot. Gesellsch., v. 73, p. $137-146$.

Madsen, E., 1963, Primitive flint culture on Isefjord: Nord. Oldkyndighed og Historie, Aarbøger 1962, p. 79-93.

Müller, S., 1907, Nye Fund og Iagttagelser fra Sten-, Bronze- og Jernalder: Nord. Oldkyndighed og Historie, Aarbøger 1907, p. 75.

Nielsen, V., 1962, The Al Wusail Mesolithic flint sites in Qatar: Kuml 1961, p. 169-184.

Olsen, O., 1964, Die Kaufschiffe der Wikingerzeit in Lichte des Schifffundes bei Skuldelev im Roskildefjord: Symposiet för Historiska Vetenskaber, Visby 1963, Stockholm, p. 20-34.

Olsen, O. and Crumlin-Pedersen, O., 1958, The Skuldelev ships: Acta Archaeol., v. 29, p. $161-175$.

Pennington, W., 1964, Pollen analyses from the deposits of six upland tarns in the Lake District: Royal Soc. (London), Trans., ser. B., v. 248, p. 205-244.

1965, The interpretation of some post-glacial vegetation diversities at different Lake District sites: Royal Soc. (London), Proc., ser. B., v. 161, p. 310-323.

Ralph, E. K. and Ackerman, R. K., 1961, Univ. of Pennsylvania radiocarbon dates IV: Radiocarbon, v. 3, p. 4-14.

Tauber, H., 1960a, Copenhagen natural radiocarbon measurements III, corrections to radiocarbon dates made with the solid carbon technique: Am. Jour. Sci. Radioc. Supp., v. 2, p. 5-11. v. 2, p. 12-25.

1962. Copenhagen radiocarbon dates V: Radiocarbon, v. 4, p. 27-34.

1964, Copenhagen radiocarbon dates VI: Radiocarbon, v. 6, p. 215-225.

Waals, J. D. van der, 1964, Prehistoric disc wheels in the Netherlands: J. B. Wolters, Groningen, p. 1-103. 